\title{
EVALUATION OF THE EFFECTIVENESS OF MANAGEMENT AT THE NORTH CHINA UNIVERSITY OF TECHNOLOGY IN BEIJING
}

\author{
KMECOVÁ Iveta, CZ
}

\begin{abstract}
Quality education is the greatest asset for the individual and allows him to successfully integrate into the practical life. Evaluation of the quality of education is therefore justified. Within the paper I present partial results of surveys aimed at identifying the views of staff and students on the quality of the course management. The aim was to determine the attitude and view of teachers, where they see options for the modernization and innovation learning process, as well as to determine student attitudes and opinions towards the level of motivation, motivational techniques, teaching methods, textbooks. The aim was to obtain feedback from the students' perspective. The study was conducted at NCUT in Beijing, China. The conclusion consists of practice recommendations to improve motivation.
\end{abstract}

Key words: quality of educational process, effeciency of educational process, education, didactic means, motivational methods, teaching methods, teacher, student.

\section{HODNOCENÍ EFEKTIVNOSTI MANAGEMENTU NA SEVERNÍ ČINSKE UNIVERZITĚ V PEKINGU}

\section{Resumé}

Kvalitní vzdělání má největší př́inos pro jednotlivce a umožňuje mu úspěšně integrovat do praktického života. Hodnocení kvality vzdělávání je proto oprávněné. V příspěvku se představí dílčí výsledky průzkumů zaměřených na zjištění názorů pracovníků a studentů na kvalitu řízení kurzu Management. Cílem bylo zjistit postoj a názor učitelů, kde nalézají možnosti pro proces učení modernizace a inovace, jakož i ke stanovení postoje a názory studentů na úrovni motivace, motivační techniky, vyučovací metody, učebnice. Cílem bylo získat zpětnou vazbu z pohledu studentů. Studie byla provedena na NCUT v Pekingu, Č́na. Závěr se skládá z praktických doporučení s cílem zlepšit motivaci.

Klíčová slova: kvalita vzdělávacího procesu, efektivita vzdělávacího procesu, vzdělávání, didaktické prostředky, motivační metody, vyučovací metody, učitel, žák.

\section{Introduction}

In all areas of life, the quality is currently an important mean. The quality of product or service is assessed individually, therefore it is subjective. This is true even when considering the quality of education. The quality of educational institution is also an objectively demonstrable, which is important, not only in terms of the whole society, as well as individual, especially in terms of decisionmaking personality when choosing a school or making a decision of specific study department. Everyone has a choice of studies. This creates education market competition.

The school provides a service to its partners, students, parents, employers and so on. Successful may currently be the only school that will have a good level, would provide quality training to its students and promote the multilateral development of their personality.

If it wants to succeed in the competition it has to necessarily pay attention to the continuous improvement of the teaching process. In order to provide quality education, it is necessary for teachers to work with new teaching methods, modern teaching concepts, innovative didactic resources as well as topical teaching aids. It is important to note that the quality of training of students is dependent and 
professional, moral profile of teachers and motivation. Only a creative, innovative teacher who uses the classroom in many educational and motivational methods and new teaching resources, can increase student interest in the subject, to awaken their activity as well as increase the efficiency of the teaching process and successfully achieve objectives. We can say that the outcome of quality education is quality education, which is the greatest wealth for the individual and allows him to successfully integrate into the practical life. Evaluation of the quality of education is therefore justified.

In this research we present partial results of the survey focused on motivation, motivation factors and motivational methods, because we believe that motivation is a crucial determinant, which has a significant impact on increasing the efficiency and quality of the educational process.

\section{The quality of the educational process}

Two basic criteria testy of school's quality (Bajtoš, 2010, according to Zelina, 2006): performance criteria (amount of knowledge and experience which has student obtained and its applicability in practice) criteria of influence (formation of personality, value criteria, motivation necessary for further learning towards to self-cultivation).

According to this, we can say that the effect of school education consists primarily in the success of the process of education and learning. The main persons involved are the teachers and students / pupils.

The teaching process is the most important of all processes at school. The quality of teaching process is a crucial element for quality of schools as well.

If the school wants to create quality it should (Bajtoš, 2010)

- innovate within the school,

- constantly improve the learning process,

- have a clear vision of its aim,

- reflect the interests of students / pupils, parents, employers,

- support the development of academic and teaching staff,

- constantly communicate the quality of its schools etc.

Our opinion is that innovation and quality in today's global world is an effective tool to tackle competitiveness. As Turek (2004) describes, the conditions to ensure the permanent innovation, not only in the sphere of industry but also services, is the quality of education. Kmecová (2010, p. 16 according to Turek 2008): "Quality education is the answer to challenges of the future." Based on the quote, we claim that the future of our nations and humanity depends on the quality of education.

Therefore, all schools (Kmecová, Bajtoš 2010 Bajtoš, 2007) should realize the fact and take necessary steps to ensure quality of education. Education should be directed to obtain the main, general and professional competencies and practically oriented knowledge and skills. Graduate should get an education, through which he would be able to adjust flexibly to changes in the labor market and be able to apply knowledge in the related fields. In this context, we point out the need to continuously linking theory with practice. Only then can we adequately prepare graduates for the labor market.

\section{The status of teacher in didactic system and the importance of motivation}

Proceeding from the above-mentioned facts, we note that the duty of every school at present should be to ensure the quality of training for future career. This quality can significantly affect teachers, because the professionalism of teachers and their active approach of leading their students / pupils, is dependent on the quality of education process. 
The teacher is therefore crucial element of achieving changes in quality of school. He or she can lift up the learning process, the quality of education through his or her subject. The teacher can through his or her methods, organization of the lesson, and positive attitude, awaken students / pupils' interest in the subject.

Kmecová (2010, p. 16), according to Maslova (2004, p. 5) states: teaching profession without contact with the new information cannot ensure improvement of behavioral-educational process and its adaptation to new conditions. A teacher that doesn't learn new things and does not acquire new information and skills cannot be beneficial for school and community. "

Quote suggests that it is important that teacher develops skills, follows new information in his or her field, learns innovation of the methodology of teaching his or her subject and applies innovations in teaching process.

According to Orbanová (2005, p. 21): "The real changes in the educational system can be realized only through initiative and creative activity of each teacher." We can say that the teacher acts as a factor of innovation changes that can through his or her conduct, approach, selection of teaching material resources, selection of appropriate teaching methods and motivational techniques, to a large extent affect quality of the education process. Teacher is a main factor in didactic system. We believe that the up to date educated teacher can positively influence meeting general goals of education as well as establishment of a fully developed personality.

In new concepts of teaching (Kmecová, Bajtoš 2010, according to Blasko 2008), it is expected that the teacher will motivate, activate, regulate, his or her students/pupils and last but not least would create a favorable climate. It is stated that when students / pupils are sufficiently motivated, we can expect better quality performance from them.

Satisfaction of students / pupils is determinant, which significantly impacts on increasing the efficiency and quality of the educational-behavioral process.

3. Motivation and motivation methods

"Motivation is the will to do", defines Heller (2001 p. 6-11). Motivated people are satisfied and can be expected to perform well. Employers receive quality work. It is Important, to determine the needs of their workers by their employer and help them to fulfill their satisfaction. If we give employees the right incentives, they work well and contribute to the profitability of the business.

Our view is that even at school they should apply the same rules. The basis of understanding motivation in the process of teaching is to understand the behavior of those around them, but also behavior of themself. (Slavík and co-workers, 2012).

If we were able to awaken inner motivation in students/pupils, we could expect satisfactory performance from them. Motivation is therefore a prerequisite for successful learning.

It is important to note that just through motivational techniques and positive approach, the teacher manages to keep attention. Therefore, regular use of different motivational techniques during exercise or lesson is justified.

\section{Motivation methods during a lesson}

Entry motivational methods

Hrmo and co-workers (2005), Bajtoš (2007) in their publications distinguish the following breakdown of input motivational methods: this method is used to attract attention and interest of the students in the beginning of the course.

- motivational stories - concrete and emotional debate, teacher tries to induce students to the natural situation,

- Motivational interviewing - a teacher leads the students / pupils dialogue, and activates their knowledge and experience. 
- motivational demonstration - the deliberate creation of a student's experience by simulating phenomena and processes,

- problematic situation as motivation - inducing problem situations that attract the attention of the student.

According to both authors aim utilization of input motivational methods attract attention and interest of the students in the beginning of the course.

Continuous motivational methods by Bajtoše (2007):

- motivational challenge- teacher asks students to pay attention, to help classmate, etc.,

- Update of the content of the curriculum - teacher approaches and combines curriculum with examples from life, allowing to creatively supplementing the content, etc.,

- praise, encouragement, criticism - are important elements of the ongoing motivation. It is necessary to praise the slow learners, even their partial successes, and encourage them to other work. On the other hand, criticism is not to be criticized for focusing only on the flaws, but to be constructive.

Author (2007, p. 165) also states: "From the description of motivation in teaching shows that it is not only target of lesson, or only encourage pupils to learning activity, or commanding. It's especially thoughtful teachers approach throughout the teaching unit, it means all the activities to themselves and students.

Following the before mentioned it is beneficial to seek the opinions of students on motivation, motivational methods applied in order to positively affect the learning process of students and achieve the objectives of the educational process.

\section{Survey of opinions and attitudes of students applying motivational and teaching methods in the lessons of Management}

Author of the survey was realized from December to January 2016 at North China University of Technology (NCUT) in Beijing, China.

\section{The aim of the survey}

Evaluate opinions of students of NCUT in Beijing to the level of motivation, motivation factors and applied motivating teaching methods, which are positively affecting learning activities. Goal is to propose recommendation based on the analysis and evaluation of the overall student satisfaction with the subject of Management

\section{Partial aims}

- seek the views of students which of teaching methods used they would recommend in order to be interested in the subject,

- Determine which method of motivation teacher uses the most in the beginning of the lecture

- determine which of the motivating factors have the most positive impact on the learning process of students,

- seek the views of students on improving teaching quality and how improved motivation positively affects their learning activities,

- Identify which innovative devices are used the most often

- propose recommendations for improving of teaching of Management subject 


\section{Object of the survey}

Opinions and attitudes of students towards motivational techniques applied, and teaching methods of NCUT in Beijing, China.

\section{The sample survey}

Our exploratory sample at the University of Beijing, consisted of a total of 64 respondents, they were two groups of students. The first group of respondents was students, who had the subject Management in the ordinary course of study, they were Chinese students in the number of 49 persons. The second group of respondents was students of Erasmus in the number of 14 people.

\section{Methodology and organization}

The study was conducted in the months of December-January 2016 at NCUT in Being in China through the author personally. Implementation of the survey was agreed in advance with the school.

Questionnaire method was used for realization of a survey. The students expressed their opinions on 10 questions (items), of which 2 were Curriculums questions 6 closed and 2 open questions. The result was finding out how the students are, satisfied with applicable motivational and teaching methods of Management subject at NCUT in China. We were also flinging out, which factors make students most motivated to make them interested in the subject. The contribution focused on the recommendation to increase the efficiency and quality of the teaching process.

\section{Partial results}

Question 1 Are you satisfied with the overall deployment of exercise in the subject of Management?

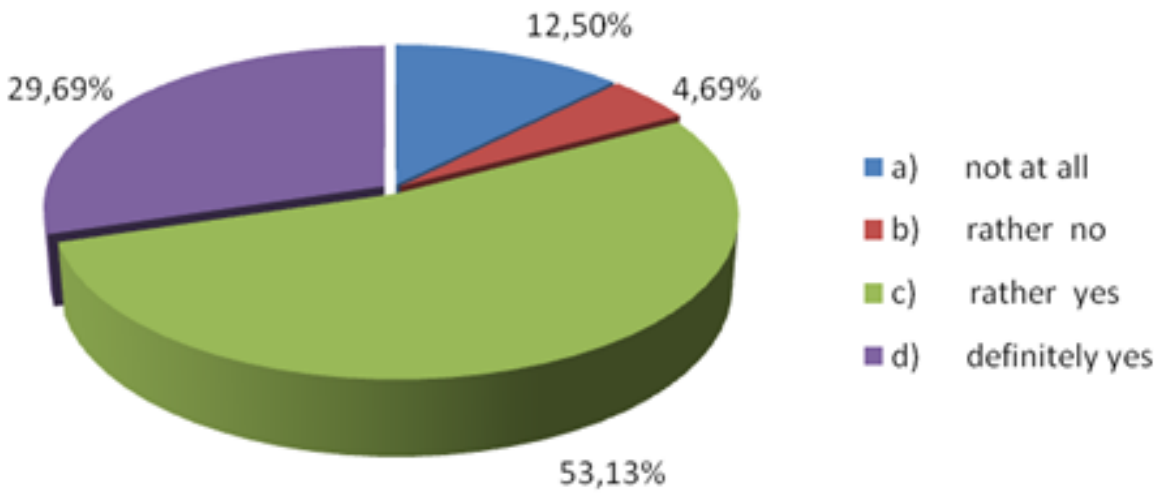

Fig. 1 Respondents express their views on overall satisfaction with the exercise

Question 2 Which of the following teaching methods would you recommend the most which interests you in the subject and motivates you to higher performance?

The aim through questions 2, was to find out which teaching methods would be the most recommended that interests students in the subject and also motivates them to higher performance. The results are given in the Table. 2, graphical view in Fig. 2. 


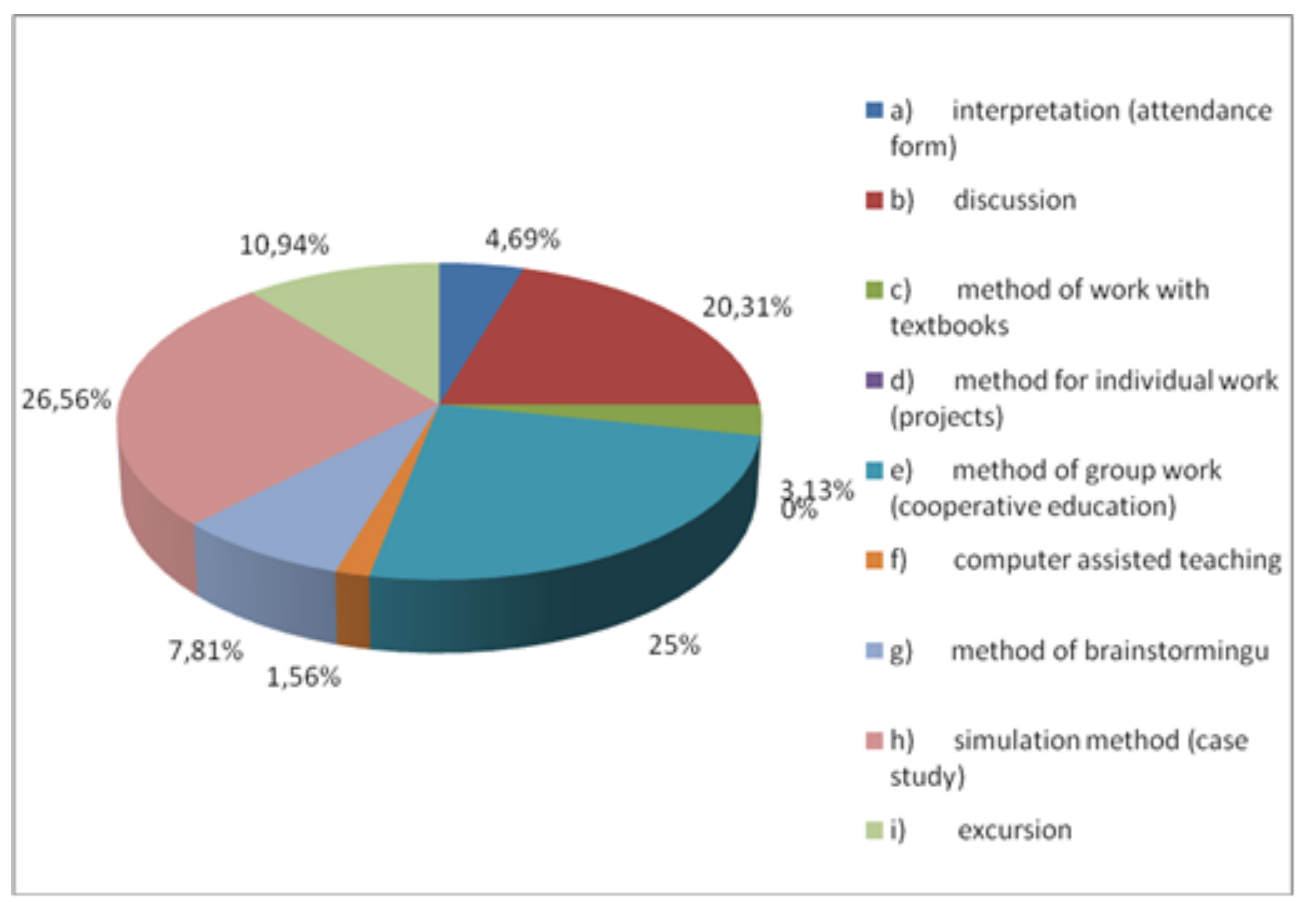

Fig. 2 Expression of the opinion of the respondents to use the teaching methods of interpretation

Question 3 What is your opinion on improving the quality of teaching of the subject Management and improvement of motivation to positively impact your learning and increasing interest in the subject?

Tab. 3 shows respondents 'answers to question 3, the aim was to find out students' opinions in respect of factors, to improve the quality of teaching and increase motivation. Graphical representation of respondents' answers can be seen in Fig. 3.

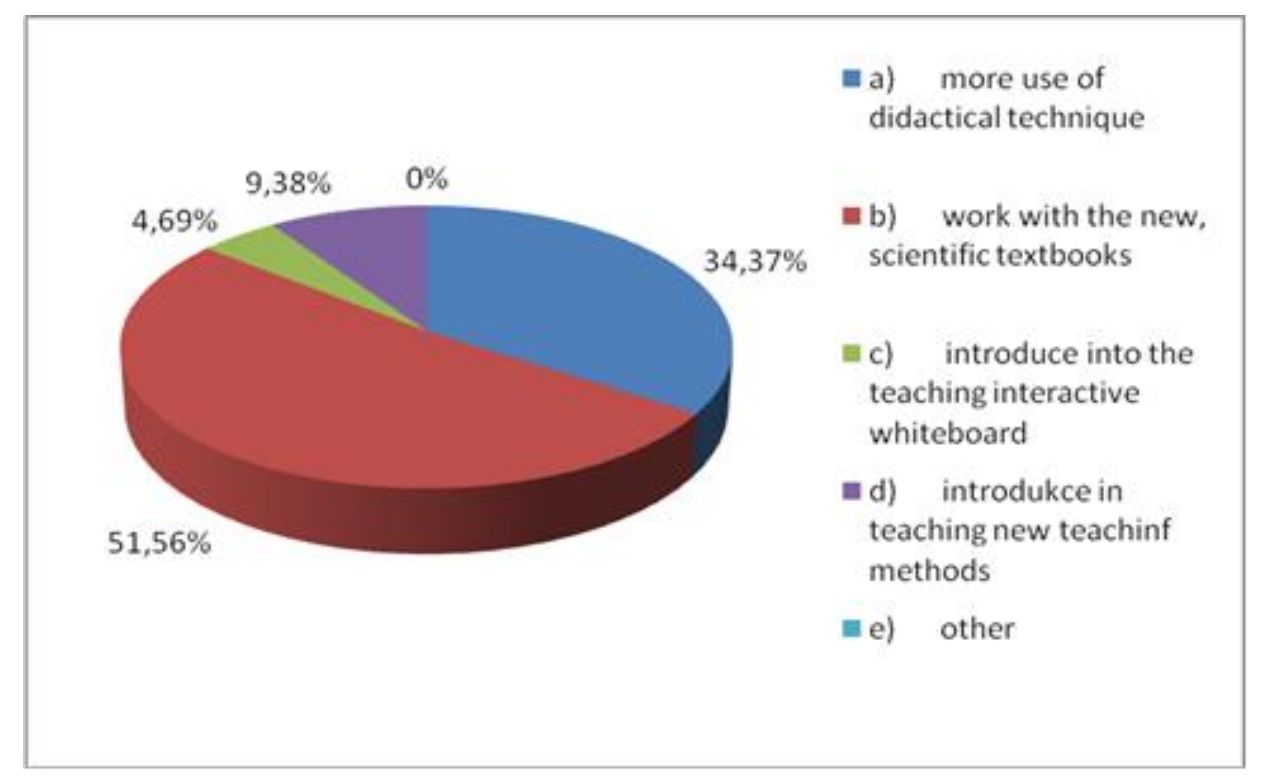

Fig. 3 Respondents' views on improving the quality of teaching and improving motivation positively affecting their learning activities 
Question 4 Which of the following factors motivates you the most in learning? The aim of questions 4 , was to find which motivating factors motivate students to learn the most.

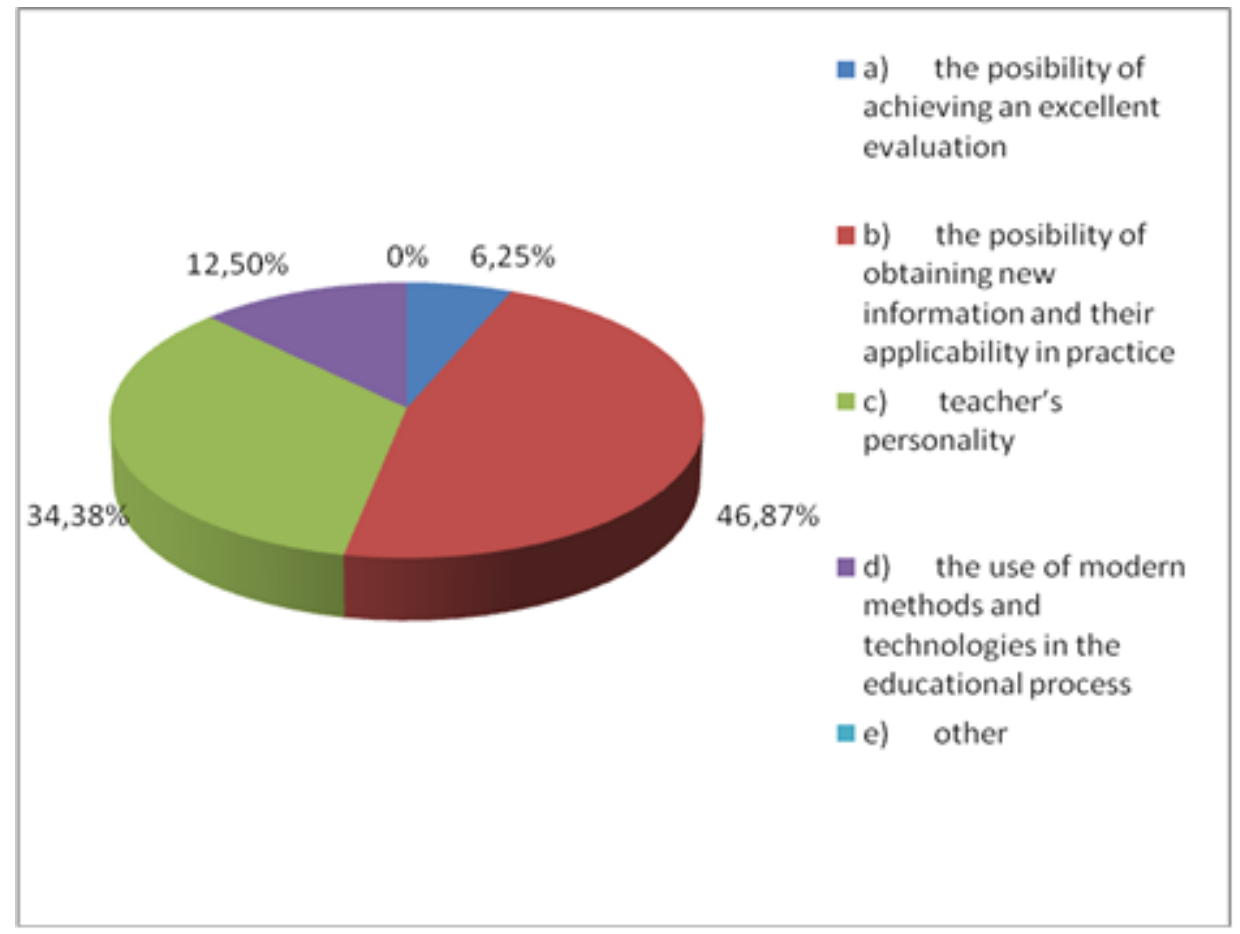

Fig. 4 Respondents' views on the motivational factors in learning

Question 5 which motivational methods teacher uses the most in order to increase interest in the introduction of exercise?

Aim through question 5 was to find out what is the initial incentive method most frequently used by teachers as an exercise. The view of respondents is expressed in Tab. 5, a graphical view in Fig. 5 .

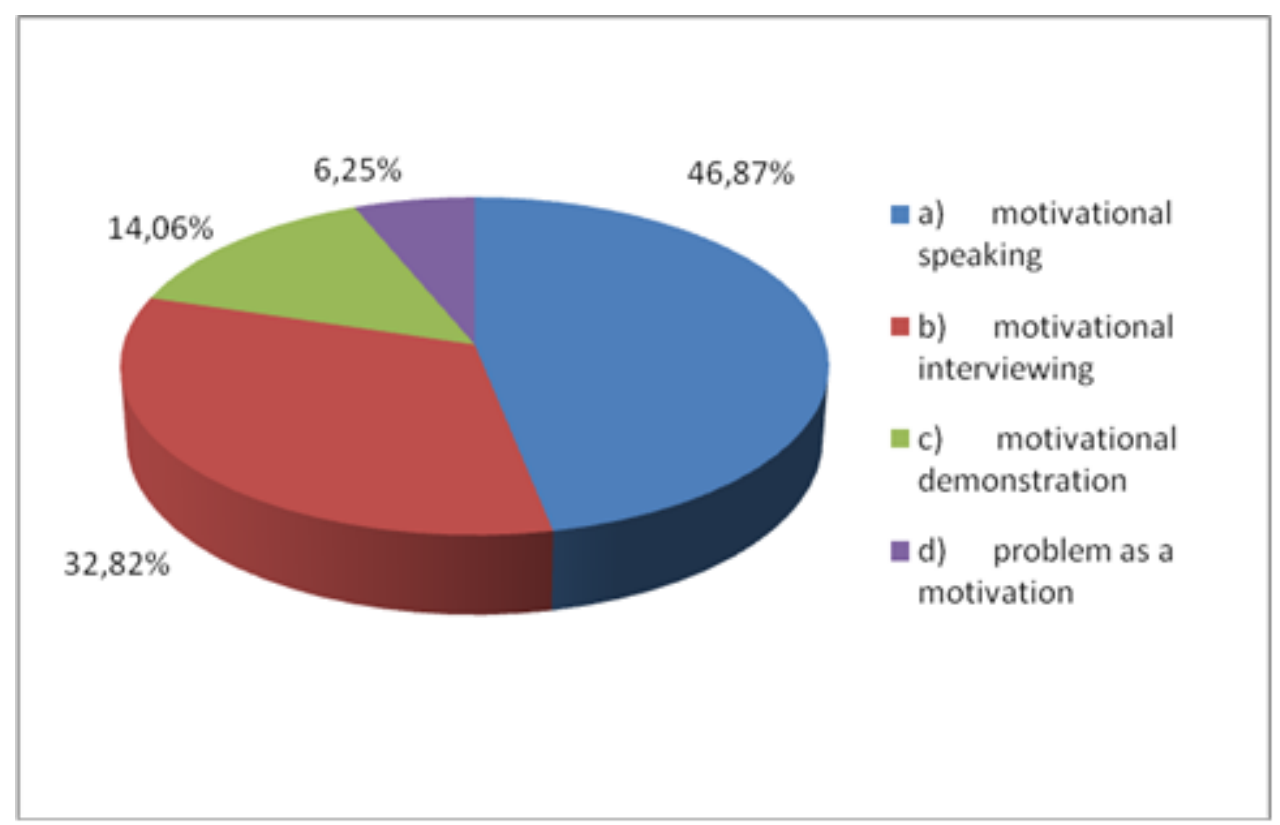

Fig. 5 Respondents' views on the use of introductory motivational methods 
Question 6 what innovation mean in teaching do you encounter most often with

Question 6 seeks, which innovative resources that are shown in Table. 6, students at the University of encounter most often with. Opinions of respondents graphically displays Fig. 6.

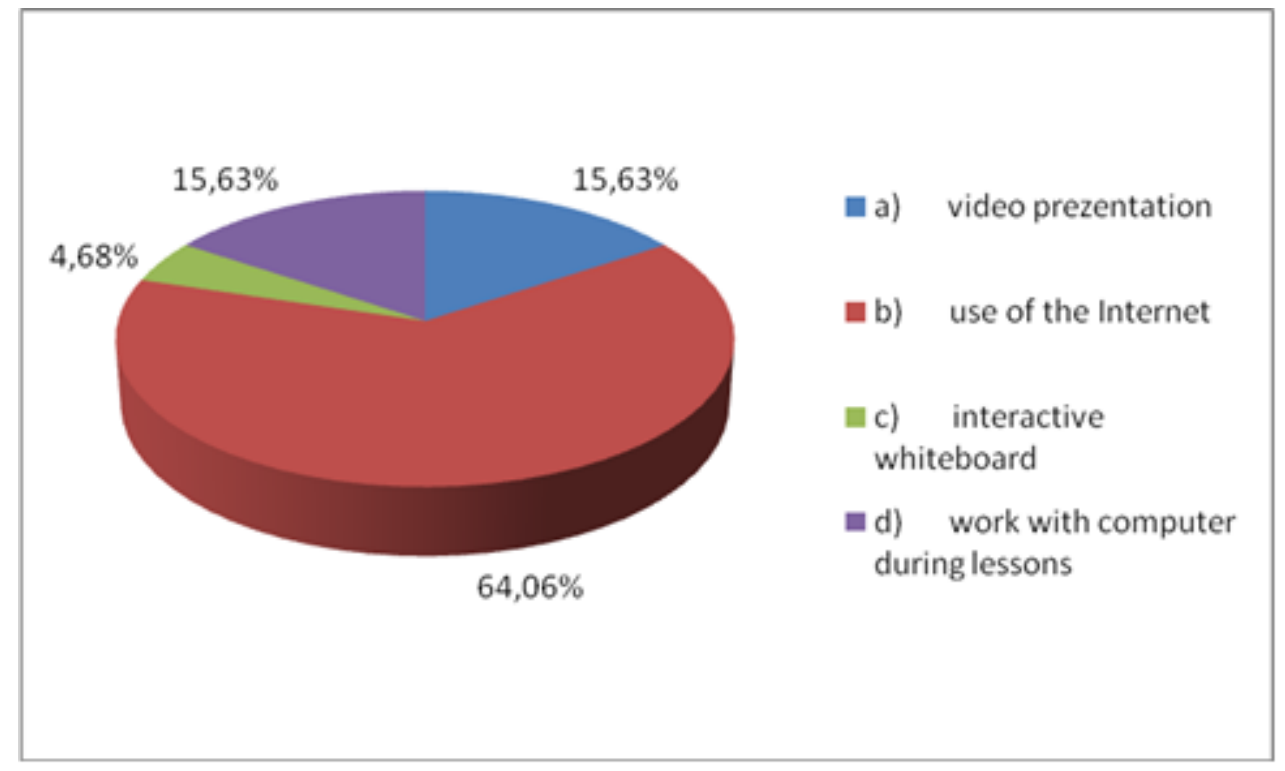

Fig. 6 Innovative means in the teaching process

\section{Discussion}

Question 1: From Tab. 1 expresses the opinion of the respondents to the overall satisfaction with the course tutorial of Management, where we can see that most students, $53.13 \%$, commented on the possibility c) rather yes, which we consider a positive result in relation to the quality provided in the exercises.

Question 2: By Question 2, the aim was to find out what teaching methods would be most recommended that interested them in the subject and also motivated them to higher performance. The results given in the Table. 2, where we can see that 17 respondents out of a total of 64 , a percentage of $26.56 \%$, would recommend simulation teaching method. This method affects satisfaction with the educational process. Using case studies, the student can acquire knowledge that in the future may be used in practice which the students are interested in and motivated at the same time in the learning process. The second method they would recommend would be a debate that marked $20.31 \%$ of respondents.

Question 3: Material didactic resources and teaching methods arise in the context of the educational process, their importance and their active use and up to date effect can largely affect the efficiency of the teaching process. Tab. 3 shows respondents' answers to question, which was examined which of these elements in the words of the students improve the quality of teaching and increase motivation in the learning process. We were surprised by the finding that most respondents circled option b) work with new scientifically-date textbooks. This option is chosen by $51.56 \%$ of the students. A relatively high percentage of students, $34.37 \%$, chose the possibility of a) greater use of didactic technique.

Question 4: From Tab. 4 shows that $46.87 \%$ of the students chose letter b) the possibility of obtaining new information to be used in practice. Relatively high percentage. $34.38 \%$ chose as a motivating factor personality of the teacher. It gives us an interesting insight, we express the opinion that the students at the Chinese University appreciates the professionalism and attitude of teachers, because according to them, it is a main factor in the learning process that may prove professionalism, students access to a significant extent affect the quality of the teaching process. 
Question 5: Motivational methods aim to arouse students' interest in learning activities. Attract genuine students' interest in learning, develop in a desire for lifelong learning, but it is especially challenging task for teachers. As motivational methods are used throughout the course of the exercise, it is necessary to recognize that fact during the preparation for a specific exercise. Expression of the opinion of the respondents to question 5, what initial motivation methods used by teachers frequently (at arousing interest in learning activities), is listed in the Table. 5. Respondents' answers are graphically illustrates in Fig. 5. Chart 6 shows that only $46.87 \%$ of students circled option a) motivational stories. Teachers use the most motivational method - motivational stories at the beginning of an exercise.

Author Bajtoš (2007) describes motivation narration as emotional and evocative verbal approximation of what the students are waiting for in particular exercise. The possibility b) motivational interview, the teacher leads the students to interview and asks questions, activates knowledge and experience, expressed by $32,82 \%$ of the students.

Question 6: Tab. 6 and Fig. 6 shows that the percentage of students, most $64.06 \%$, indicated for the most commonly used innovative means of using the Internet as part of the exercise.

\section{Conclusions and Recommendations}

The present study was conducted in the months of December and January of year 2016 at NCUT University in Beijing, China. The author conducted survey. The survey confirmed the following:

- students are satisfied with the overall undergoing of subject Management,

- methods that were the most recommended for University of Beijing by its students in order to interest them and also motivated them to higher performance, were mainly two methods: simulation method and discussion,

- didactically most effective means of teaching material that includes a new, scientifically current textbooks, which improves the quality of teaching and arouses interest by motivating learning activities was the most important for students of this university,

-the most students consider motivating factor to be the possibility of acquiring new information that can be applied in their lives as well as personality of the teacher,

- according to the students, teachers most commonly use motivational stories out of introductory motivational methods,

- the most frequently used innovative means of students reported was using of the Internet as part of the exercise.

Due to the conclusion, by teacher in Beijing you would recommend:

- allow students to engage in conversation : teacher- student, student - student, to develop discussions with students which they consider motivational,

- interpretation of the new curriculum alongside with deepening of practical activities, practical examples and usage educational technology,

- enrich the interpretation of subject with activity related to the work with PC, new teaching methods and teaching programs,

- implement new scientific materials, text books and texts into teaching process,

- last but not least, continue to seek the opinion of students on the quality of teaching. 


\section{What to conclude?}

It is important to evaluate the quality of education, to know the strengths and weaknesses of the teaching process. It is a feedback even for teachers, because without knowledge of students' opinions on the quality of teaching, we cannot significantly affect the motivation and satisfaction of students and therefore achieve the stated objectives of educational process.

\section{Bibliography}

1. BAJTOŠ, J. Kapitoly zo všeobecnej didaktiky. EQUILIBRIA,s.r.o., 2007, 274 s. ISBN 978-8089284-08-5

2. BAJTOŠ, J. Implementácia mikrovyučovania do pregraduálnej prípravy prípravy učitel'ov v podmienkach PF UPJŠ v Košiciach. In Zborník príspevkov z medzinárodnej vedeckej konferencie Integrácia teórie a praxe didaktiky ako determinant kvality modernej školy. Košice, 2010. ISBN 978-80-7097-843-6

3. BLAŠKKO, M. Úvod do modernej didaktiky II. (Riadenie kvality v škole). KIP TU. Košice 2008. ISBN 978-80-553-0051-1

4. HELLER, R. Effectual motivation. Banská Bystrica: Vydavatel'stvo Slovart, spol. s.r.o. v spolupráci s týždenníkom TREND, 2001. ISBN 80-7145-556-3

5. HRMO, R. a kol. Didaktika technických predmetov. Bratislava: STU, 2005. ISBN 80-227-21913.

6. KMECOVÁ, I. Didaktická účinnost’ učebníc v odbornom vzdelávaní. STU Bratislava: Vydala MTF Trnava, 2010. evid.č.: MTF 109-01-52770.

7. KMECOVÁ, I. a J. BAJTOŠ. Sledovanie didaktickej účinnosti učebníc v odbornom technickom vzdelávaní vyučovacieho predmetu Ekonomika. In: Integrácia teórie a praxe didaktiky ako determinant kvality modernej školy. Zborník príspevkov z medzinárodnej vedeckej konferencie. Košice 2010, s. 302-313, ISBN 978-80-7097-843-6

8. MASLOVÁ, M. Inovácie v škole II. Dolný Kubín: Tlačiareň Vrábel, 2004. ISBN 80-968-664-51

9. ORBÁNOVÁ, D. Didaktika podnikovej ekonomiky. Bratislava: Vydavatel'stvo EKONÓM, 2005. 213 s. ISBN 80-225-2005-5

10. SLAVÍK, M. a kol. Vysokoškolská pedagogika. Praha: Grada Publishing, 2012. ISBN 978-80247-4054-6.

11. TUREK I. Didaktika. 1. vyd. Bratislava: Iura Edition, spol. s r. o, 2008. ISBN 978-80-8078-1989

12. TUREK, I. Zabezpečenie kvality výchovy a vzdelávania v základných a stredných školách v štátoch EÚ. In: Pedagogické rozhl'ady. Banská Bystrica 2004, roč. 13, 5/2004, s 2-4, ISSN 1335- 0404

13. ZELINA, M. Kvalita školy a mikrovyučovacie analýzy. Bratislava: OG - Vydavatel'stvo Pol'ana, 2006. ISBN 80-89192-29-7

\section{Address:}

Iveta Kmecová,Ing., PhD.

The Department of Management, The Institute of Technology and Business in České Budějovice in the Czech Republic, Okružní 10 Street, 37001 České Budějovice

e-mail:kmecova.ivet@vstecb.cz 